\title{
Parasite transfer from crustacean to fish hosts in the Lübeck Bight, SW Baltic Sea
}

\author{
C. D. Zander, S. Groenewold \& U. Strohbach \\ Zoologisches Institut und Zoologisches Museum der Universität; Martin-Luther-King- \\ Platz 3, D-20146 Hamburg, Federal Republic of Germany
}

\begin{abstract}
Four helminth parasites out of 19 species found in the Lübeck Bight, Baltic Sea, were chosen for investigations on the transfer from invertebrate to small-sized fish hosts: larvae of the tapeworms Schistocephalus sp. and Bothriocephalus sp. (Cestoda) living in planktonic copepods as primary hosts; Podocotyle atomon (Digenea) and Hysterothylacium sp. (Nematoda) were found in benthic crustaceans, especially Gammarus spp. These hosts were the prey of 3 gobiid fishes, Gobiusculus flavescens (feeding mainly on plankton), Pomatoschistus minutus (preferring benthos), and $P$. pictus (feeding more on plankton than benthos). Because the fishes selected smaller sizes of crustaceans, they ingested all stages of the copepods but only the smaller-sized groups of gammarids which were often less infested by parasites. In order to evaluate the probability for a fish to be parasitized by a helminth ${ }_{r}$ an infestation potential index (IP) was calculated. Podocotyle atomon and Hysterothylacium sp. revealed an IP which was far lower in gobies than expected when the prevalences of the previous hosts were taken into consideration. The IP of tapeworm larvae was mainly influenced by the feeding pressure of the gobiid predators, which might change with developmental stage and season. It is concluded that parasite transfer to the next host decreases when sizes of prey and predator differ only moderately. This mechanism can reduce the numbers of parasites transferred to less suitable or wrong hosts.
\end{abstract}

\section{INTRODUCTION}

Parasites are important components in marine coastal ecosystems. Many helminths present complicated life cycles, infest different hosts and, therefore, change their habitats several times. This biological characteristic can cause transportation from the water column to the bottom, or even from aquatic to terrestrial habitats (Odening, 1974; Reimer, 1983). The parasite communities in their respective hosts have increasingly become objects of research (Esch et al., 1990). First Esch et al. (1975) developed an hierarchical concept for parasite populations. Three levels of parasite communities were fixed: infracommunity in a single host, component community in a host population, and compound community in a host biocoenosis. The analysis of component communities helps in identifying important parasites. The flow of parasites through several hosts is the main object of compound community research (Esch et al., 1990). The hosts are either directly infested by active larval stages (e.g. cercariae in Digenea), or by intermediate hosts, which are preyed-upon together with passive larval stages (e.g. pro- or plerocercoids of Cestoda, metacercariae of Digenea, larvae of Nematoda, acanthellae of Acanthocephala).

The transfer of larval parasites to the fish hosts became plausible when several 
authors investigated the single-host levels and their prevalences (MacKenzie \& Gibson, 1970 ; Reimer, 1970; Køie, 1979, 1983; Zander et al., 1984) but there is still a lack of results about fishes or birds feeding on infested preys.

Snails, planktonic and benthic crustaceans, as well as gobiid fishes of the Lübeck Bight (western Baltic Sea), harboured at least 19 species of digeneans, cestodans, nematodes, and acanthocephalans (Zander et al., 1993). The aim of this investigation was to elucidate their life cycles and host changes. In order to calculate probabilities of infestation and losses during the process from one host to the next, two pathways of parasite development were chosen: the prey-predator systems of copepods and fishes for Cestoda, as well as gammarid crustaceans and fishes for Podocotyle atomon (Digenea) and Hysterothylacium sp. (Nematoda). The presentation of the whole helminth fauna of crustaceans from the Lübeck Bight is included in order to get information about the relative importance of the single parasite species.

\section{MATERIAL AND METHODS}

The investigations were performed in 1989 and 1990 off Dahmeshöved, Lübeck Bight, where salinity fluctuated between 9 and $15 \%$ (Zander et al., 1993). All the material was sampled (mainly by SCUBA dives) very close to a stony pier. The gobiid fishes Pomatoschistus minutus (Pallas), Pomatoschistus pictus (Malm), and Gobiusculus flavescens (Fabricius) were collected in a depth of 3-6 m with large hand-nets, and fixed in $4 \%$ formaldehyde immediately after the diving operation had ended. A total of 461 gobies were sampled. The fishes were dissected for analysing prey components from the intestinal tracts, as well as parasites from the same organ and from the body cavity. The prey was assessed to relevant taxonomic groups and measured with a microsize device to the nearest $0.1 \mathrm{~mm}$ allowing it to be arranged into size classes of $2 \mathrm{~mm}$. The parasites were assessed to the species level (Zander et al., 1993) of which the following 4 were chosen for the present studies: Bothriocephalus sp., Schistocephalus sp. (Cestoda), Podocotyle atomon (Rudolphi) (Digenea), and Hysterothylacium sp. (cf. auctum [Rudolphi]) (Nematoda).

Plankton samples were obtained every 2-4 weeks from May to November 1989 by pouring in situ $100 \mathrm{l}$ seawater through a net of $55 \mu \mathrm{m}$ mesh-size. The copepods were selected out of the plankton samples, and transferred into a medium consisting of $70 \%$ ethanol, $25 \%$ water, $5 \%$ glycerine and 1-2 drops of borax-carmine. The parasites then became clearly visible, but could only be identified to the level of larval stages of cestodes or nematodes.

In 1990, the overgrown walls of the pier were scratched with a PE-tube into which the detached aufwuchs of the Mytilus girdle was collected; this included benthic crustaceans. The samples were fixed in $4 \%$ formaldehyde. The potential prey organisms of gobiid fishes - in particular gammarids - were separated from the aufwuchs, identified to the species level, measured as described above in order to arrange them in 2-mm size classes, and dissected in order to find larval helminths.

The following parameters were used (partly according to Margolis et al., 1982): $\mathrm{Abundance}$ : the mean number of parasites in all specimens of a host population. In te n sity: the mean number of parasites in the infested specimens of a host population. 
Prevalence: the percentage of the host population which is parasitized.

Infestation potential (IP): the prevalence of prey components in a distinct size class, multiplied with the percentage of organisms of the same size class which were ingested by the predators; the values of every size class when summed up result in the IP of the respective fish host. It expresses the probability of a predator to be infested by parasites present in its prey.

Available prey: the percentage of a size class of a prey component found in the aufwuchs samples.

Ingested prey: the percentage of a size class of a prey component found in the guts of predators.

\section{RESULTS}

\section{Copepoda}

Among planktonic copepods, Acartia bifilosa prevailed over Oithona similis, Eurytemora hirundoides and Centropages hamatus (Table 1). Whereas $O$. similis was not parasitized, the 3 other species bore cestode and nematode larvae (probably Hysterothylacium sp.).

Table 1. Mean densities and prevalences of planktonic copepods from Dahmeshöved, 1989

\begin{tabular}{|c|c|c|c|c|}
\hline Host species & 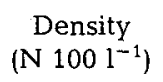 & Oncosphaerae & $\begin{array}{c}\text { Prevalence }(\%) \\
\text { Procercoids }\end{array}$ & Nematoda \\
\hline Paracalanus parvus & 0.5 & & & \\
\hline Centropages hamatus & 21.6 & 5.1 & 7.9 & 0.5 \\
\hline Temora longicornis & 8.9 & & & 1.1 \\
\hline Eurytemora hirundoides & 31.3 & 1.9 & 3.5 & 0.6 \\
\hline Acartia bifilosa & 78.6 & 3.8 & 6.0 & 1.0 \\
\hline Acartia discaudata & 1.8 & & & \\
\hline Oithona similis & 60.0 & & & \\
\hline
\end{tabular}

Cestode larvae were most abundant in July 1989 (5\% of copepods were infested with oncosphaerae, $8 \%$ with procercoids) (Fig. 1a). Lower peaks of infestation were found in April (oncosphaerae only) and October. Prevalences caused by nematode larvae increased continuously until $3 \%$ in summer, but then stopped abruptly (Fig. 1a). The population of copepods was low until August but increased extensively in autumn (Fig. 1b). Gobiusculus flavescens fed regularly on planktonic copepods in mean quantities of ca 100. In contrast, Pomatoschistus minutus only fed on this prey component in late summer and autumn (Fig. 1b).

When the copepod prevalences and the feeding rates of fishes were combined, the result was a high potential of infestation (IP) of $G$. flavescens and also of $P$. minutus by cestodes at least in October (Fig. 2). Abundance and intensity of cestodes must be considered as very low because in general 1 or, at the most, only 2 parasites were found per infested fish host. 


\section{a. Infested copepods, 1989}

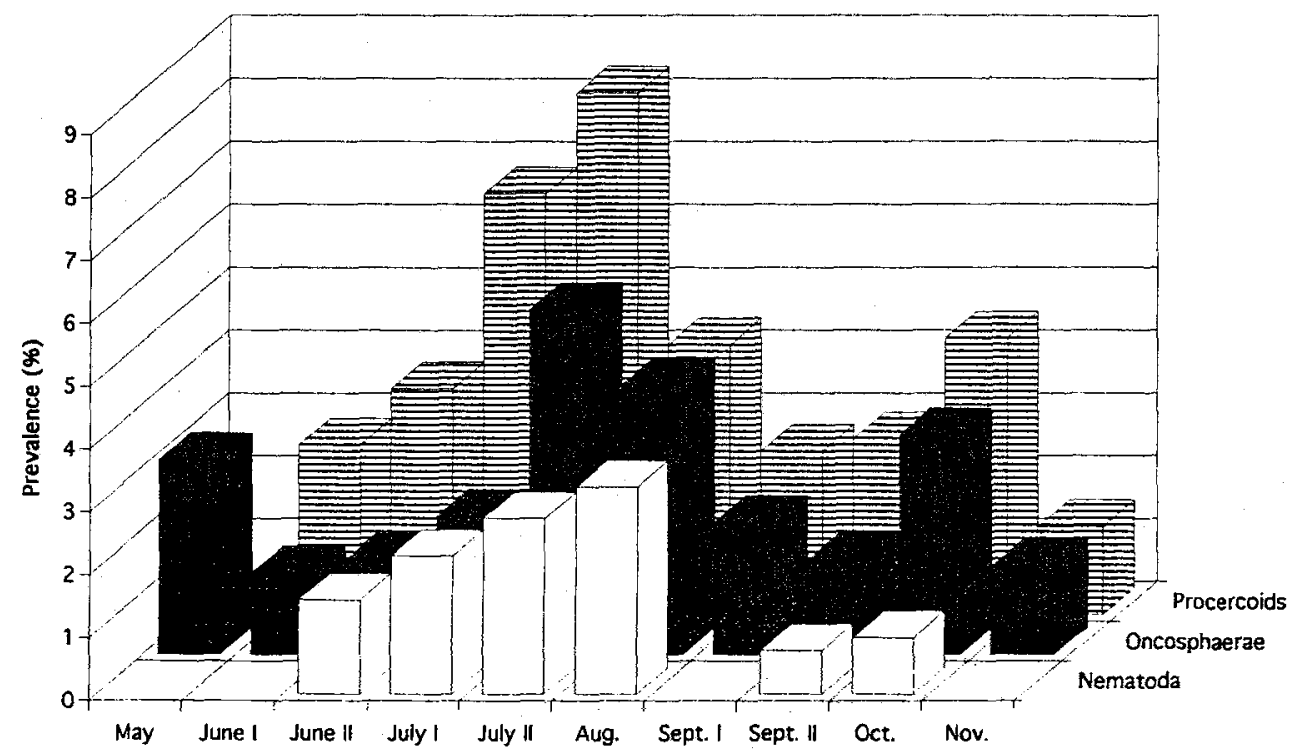

b. Available and ingested copepods 1989

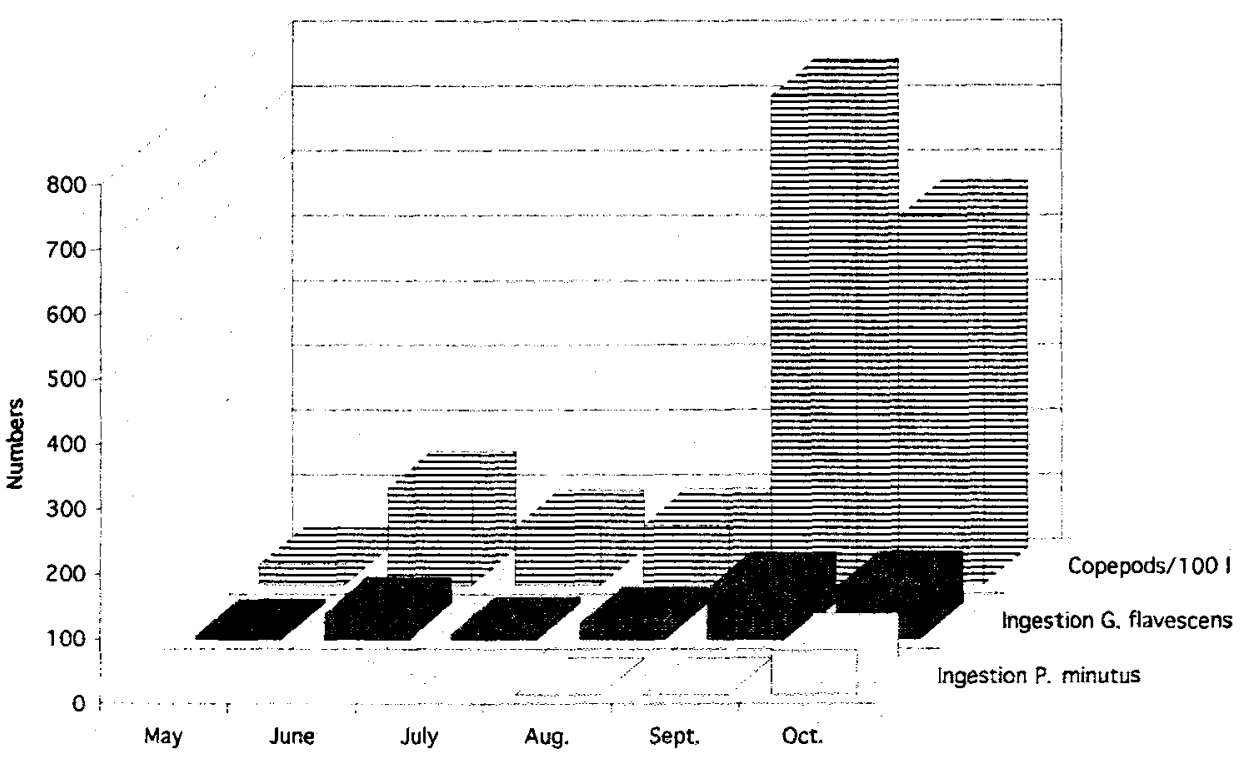

Fig. 1. Planktonic copepods in the food and parasite web of the Lübeck Bight in 1989; a: Prevalence of infestation of copepods by nematode and cestode larvae; b: Numbers of available copepods and those ingested by gobiid fishes from May to October 


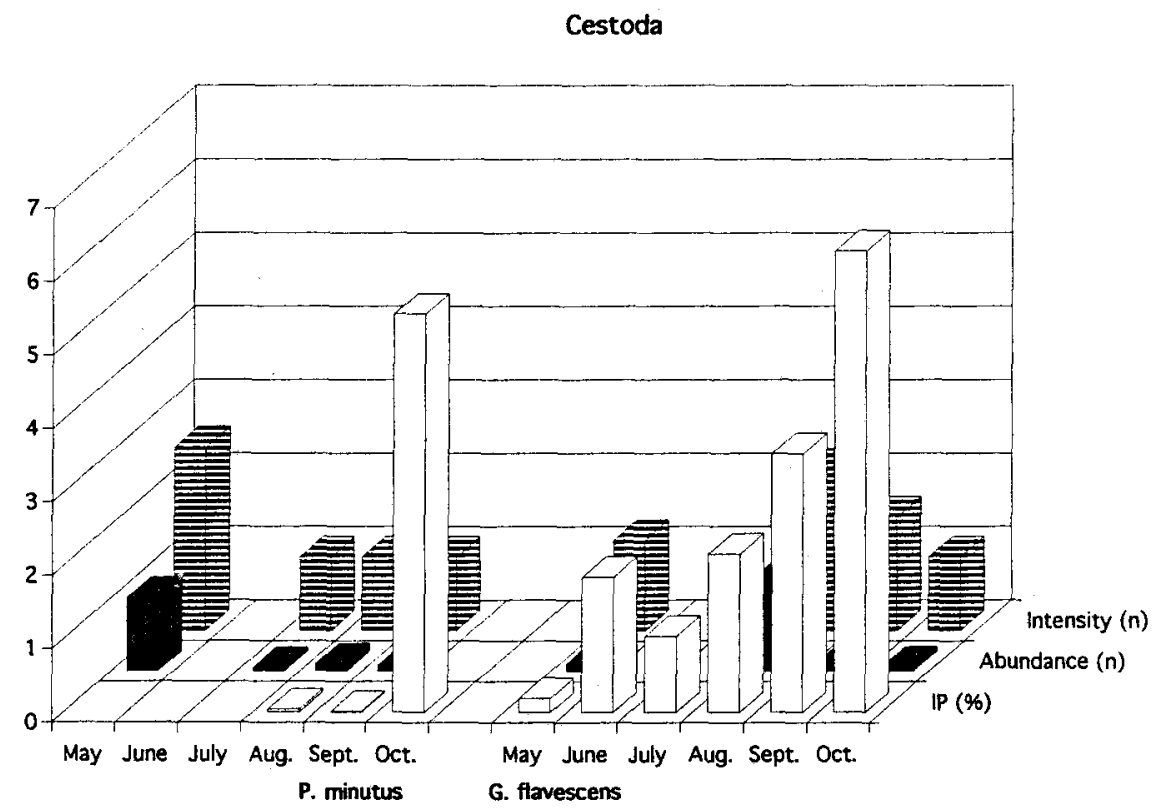

Fig. 2. Infestation potentials IP (\%) of copepods as well as abundances and intensities (mean numbers) of cestode larvae in 2 goby species parasitized during 1989

\section{Benthic crustaceans, especially Gammaridae}

Young Gammarus of less than $4 \mathrm{~mm}$ size, which cannot be determined to the species level, and Jaera albifrons were the most abundant benthic crustaceans (Table 2). Gammarus oceanicus and $G$. salinus developed large populations, whereas several Gammaridea species and Idotea balthica were less abundant. Microphallus papillorobustum was present in 9 hosts; 6 hosts harboured other microphallids, acanthellae or Hytherothylacium sp., but only 4 Gammarus spp. harboured the digenean Podocotyle atomon. Idotea balthica was not infested in the investigation area.

The benthic gammarid crustaceans were bigger than copepods and could, therefore, be arranged into several size classes. The gammarids were infested by Podocotyle atomon and three microphallid digeneans in May 1990 (Fig. 3a), but the smallest sizes were not parasitized - though they were the most abundant. Prevalences of only $1 \%$ were attained by $P$. atomon in the size classes of 6,8 and $14 \mathrm{~mm}$, whereas microphallids were spread among single size classes attaining there approx. $0.5 \%$ (Fig. 3a). The gobies preferred smaller crustaceans of 2 to $6 \mathrm{~mm}$; Pomatoschistus minutus very occasionally selected some individuals of 8 or $10 \mathrm{~mm}$ (Fig. 3b). Therefore, Gobiusculus flavescens must have accumulated its very large $P$. atomon populations from the $6-\mathrm{mm}$ size group of the transmitter only.

$P$. atomon and two of the microphallids vanished in July - but, simultaneously, nematode larvae, which might be Hysterothylacium sp., appeared (Fig. 4a). Gammarids of a maximal $8 \mathrm{~mm}$ were infested by microphallids, but smaller as well as larger 


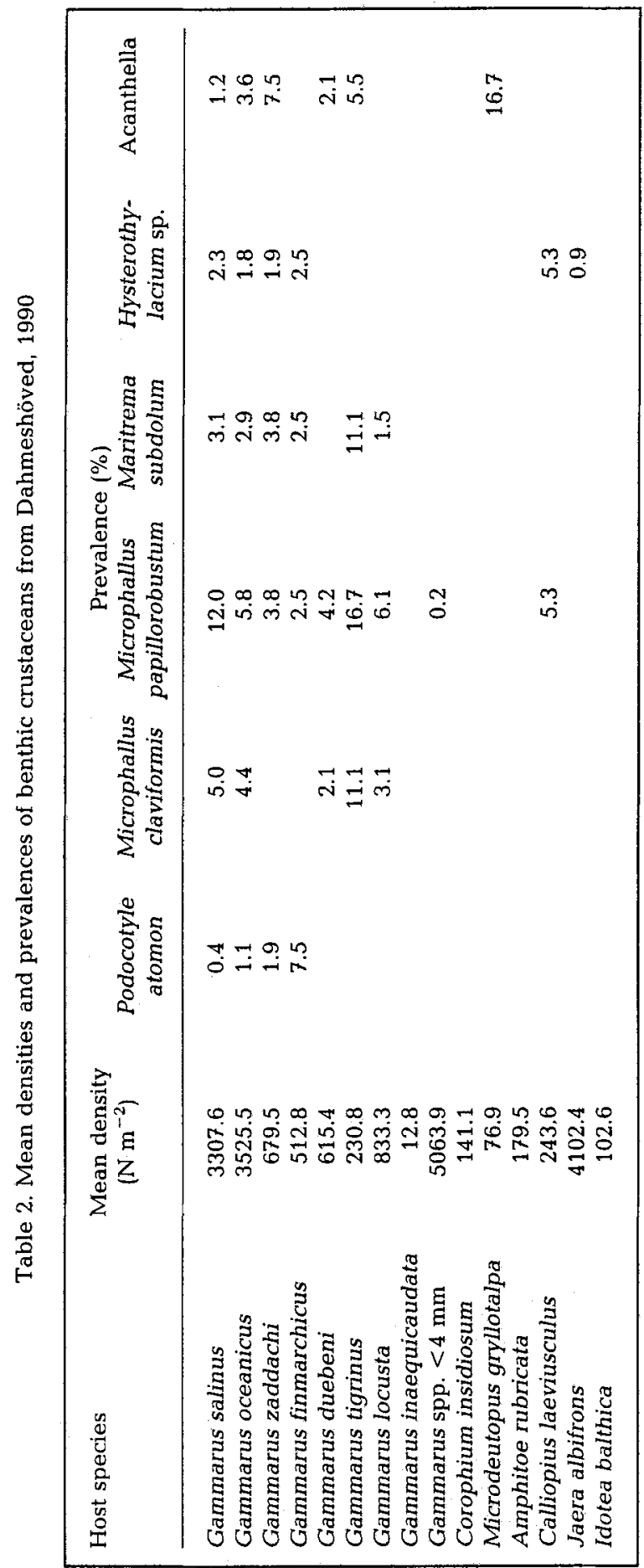


a. Infested gammarids, May 1990

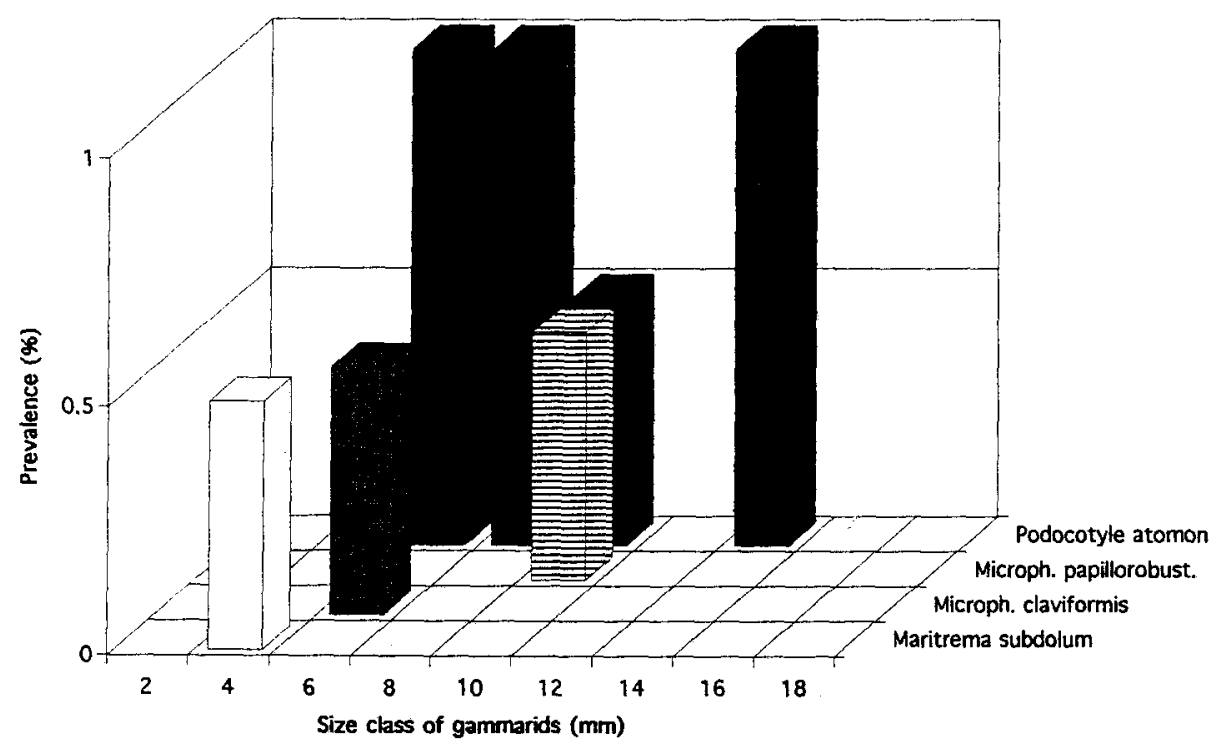

b. Available and ingested gammarids, May 1990

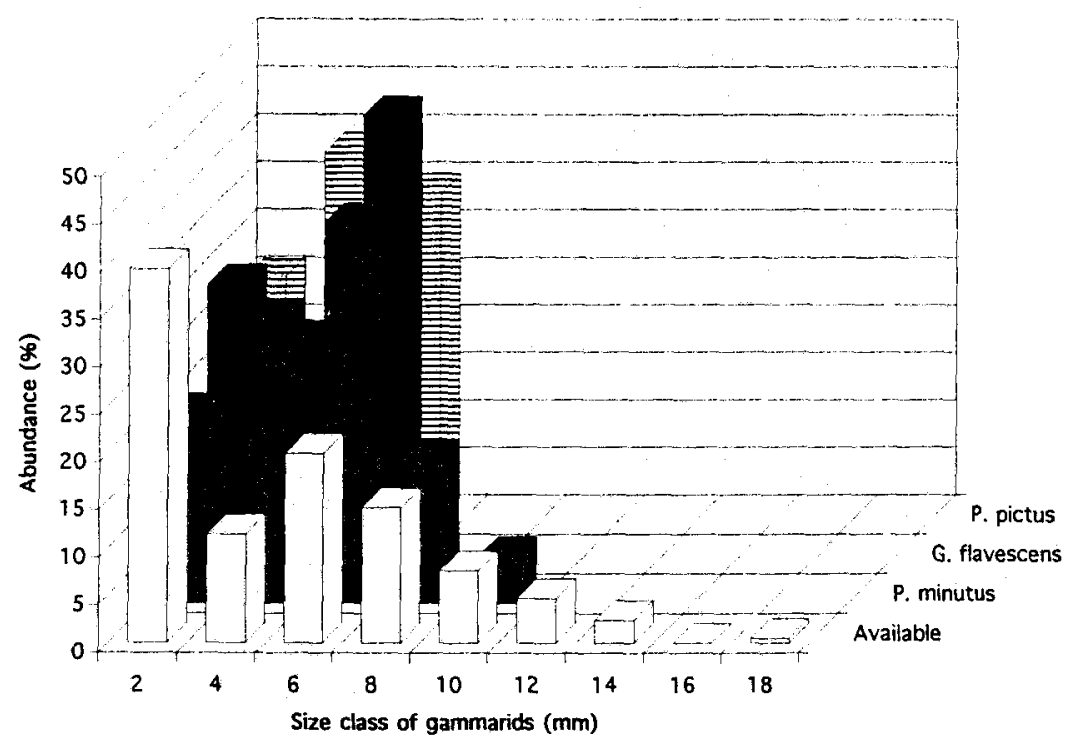

Fig. 3. Gammarid crustaceans in the food and parasite web of the Lübeck Bight in May, $1990_{\text {i }}$ a: Prevalence of infestation by helminth larvae with regard to different-sized hosts; b: Percentages of available prey and that ingested by gobiid fishes with regard to size 
a. Infested gammarids, July 1990

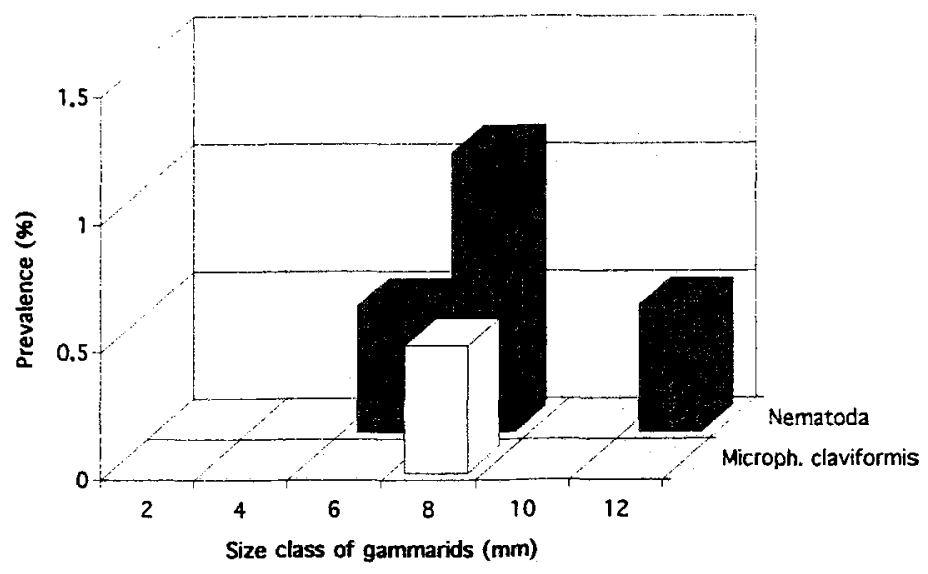

b. Available and ingested gammarids, July 1990

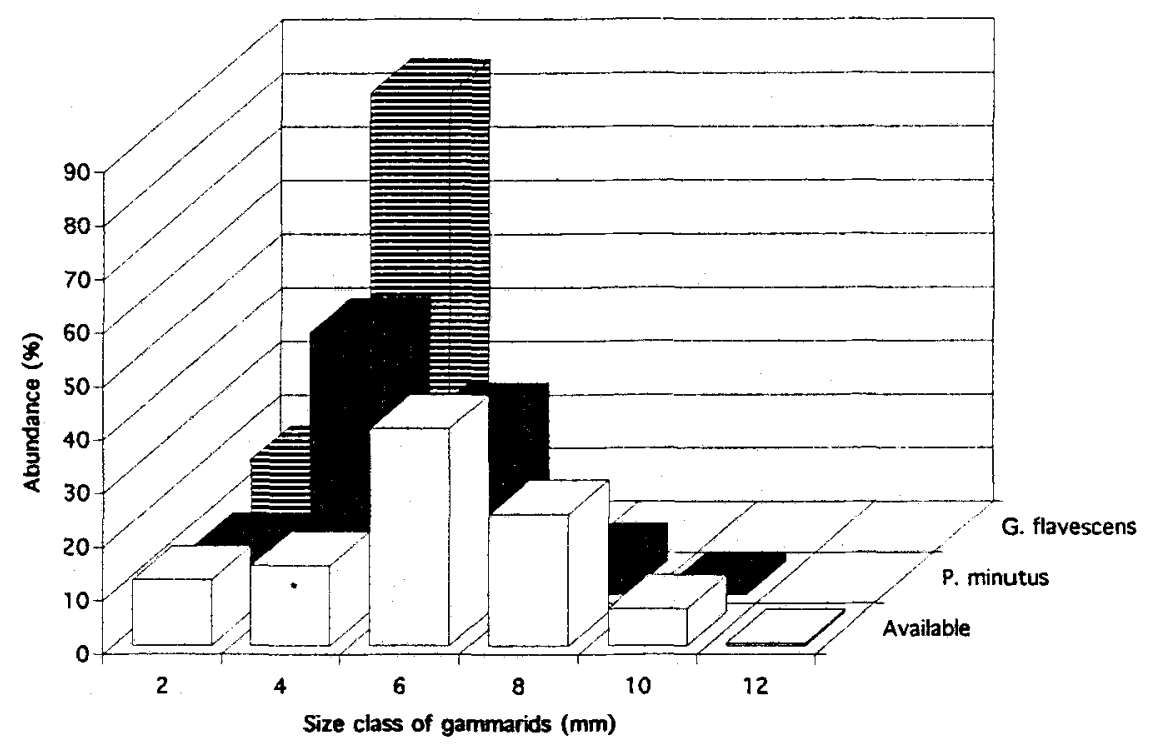

Fig. 4. Gammarid crustaceans in the food and parasite web of the Lübeck Bight in July, 1990; a: Prevalence of infestation by helminth larvae with regard to different-sized hosts; b: Percentages of available prey and that ingested by gobiid fishes with regard to size

individuals harboured nematode larvae. The size distribution of gammarids in July was between 2 and $12 \mathrm{~mm}$ with a peak at $6 \mathrm{~mm}$ (Fig. $4 \mathrm{~b}$ ). Size classes infested with nematodes were ingested by $P$. minutus, but not by G. flavescens (Fig. $4 \mathrm{~b}$ ).

The September samples revealed a spectrum of 5 parasite species in gammarids: Podocotyle atomon, acanthellae and nematode larvae, and 2 microphallid species (Fig. 5a). Within a size-range of $2-16 \mathrm{~mm}$, the most infested group was 8-mm-large 
a. Infested gammarids, Sept. 1990

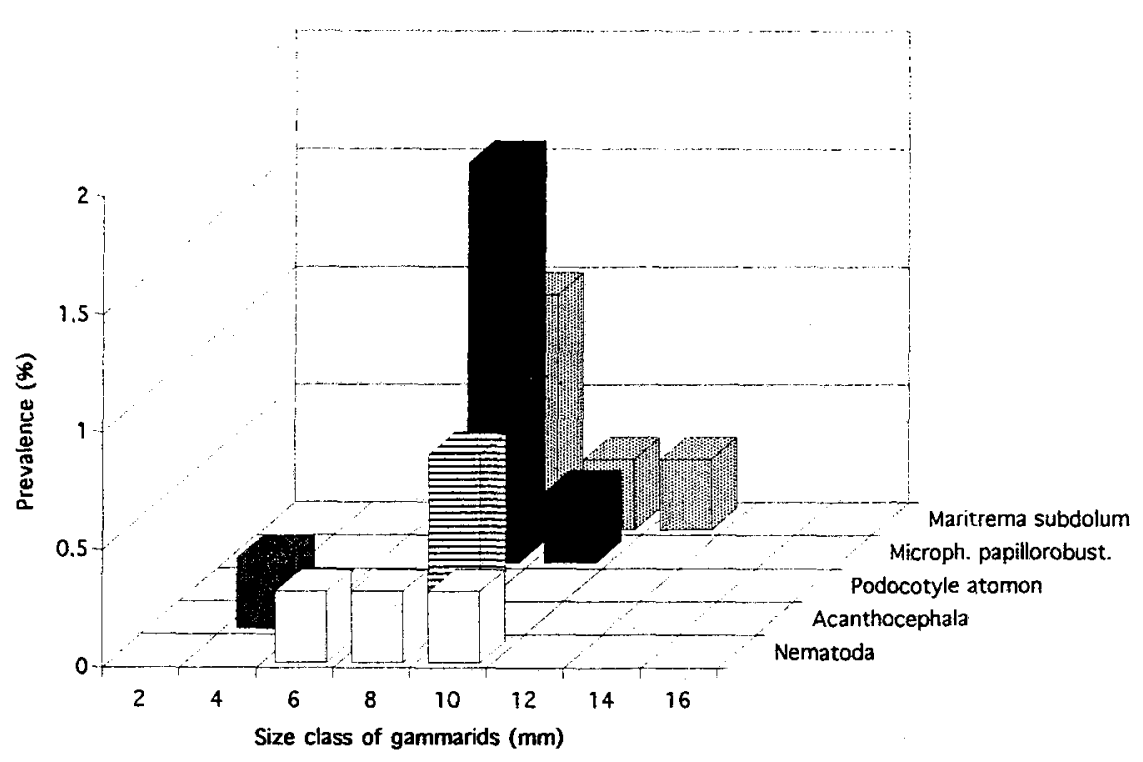

b. Available and ingested gammarids, Sept. 1990

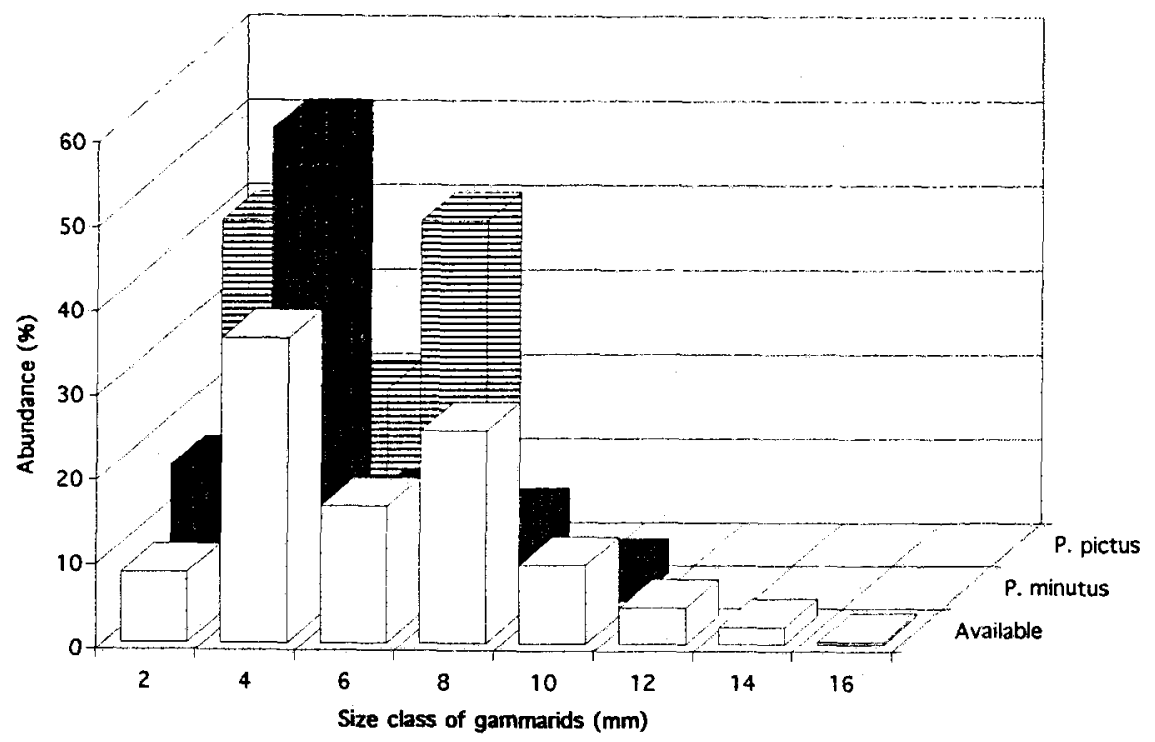

Fig. 5. Gammarid crustaceans in the food and parasite web of the Lübeck Bight in September, 1990; a: Prevalence of infestation by helminth larvae with regard to different-sized hosts; b: Percentages of available prey and that ingested by gobiid fishes with regard to size 
gammarids (Fig. 5b). Whereas Microphallus papillorobustum attained a highest prevalence of $1.7 \%, P$. atomon were only present in the $8-\mathrm{mm}$ class with $0.5 \%$ prevalence (Fig. 5a). Nematoda were found in gammarids of $6-10 \mathrm{~mm}$ with only $0.3 \%$ prevalence, acanthellae were only present in the $4-\mathrm{mm}$ group. Among available crustaceans, two peaks in 4 - and 8-mm size classes were apparent (Fig. 5b). Pomatoschistus pictus fed only on 2-6-mm individuals, whereas $P$. minutus selected even $10-\mathrm{mm}$-sized ones. Therefore, $P$. atomon might only infest $P$. minutus in this month - if one regards gammarids as transmitters.

All parasites found in September were present in October, except $P$. atomon (Fig. 6a). The parasites were concentrated in the 4- to $12-\mathrm{mm}$ size groups, only the nematodes appeared in 6- to 8-mm large hosts only. The total range of gammarids comprised $2-18 \mathrm{~mm}$; the $4-8-\mathrm{mm}$ classes were preyed on by $P$. minutus (Fig. 6b). Therefore, this goby might be infested by acanthocephalans as well as by nematodes.

The parasite spectrum comprised 5 components in November 1990 (Fig. $7 a$ ). Nematode and acanthocephalan larvae attained prevalences of $0.2-1.0 \%$ in gammarids of $6-16-\mathrm{mm}$ size. However, this sample was dominated by microphallids attaining a highest prevalence of $5 \%$ (Fig. $7 \mathrm{a}$ ). The gammarids ranged from 2 to $20 \mathrm{~mm}$ and peaked in the 4-mm group (Fig. 7b). The gobies selected prey of $4-10 \mathrm{~mm}$, which were simultaneously the main transmitters of nematodes and acanthocephalans. The size class of $6 \mathrm{~mm}$, which was preferred by Pomatoschistus pictus and $P$. minutus, was not infested by nematodes (Fig. 7b).

When the infestation potential (IP) of Podocotyle atomon was compared with the abundances and intensities of 3 goby species, clear differences became apparent (Fig. 8). The highest indices were $2 \%$ - which means that 50 prey ingestions were necessary to infest $P$. pictus with a parasite. $P$. minutus and $P$. pictus can be infested twice during the year (May, September); therefore, small populations of parasites can be found 2 months later (July, November) in these hosts. In G. flavescens, this infestion potential was lacking, because it did not feed on infested crustaceans in September (Fig. 8). All 3 fish hosts were extremely infested by Podocotyle atomon in May; this may be caused by the infestations in early spring.

The transmission rates of Hysterothylacium sp. are lower than those of $P$. atomon. The infestation potential (IP) was, for $P$. pictus, highest in September $(0.8 \%)$, and for P. minutus, in July (0.4\%) (Fig. 9). Also, intensities and abundances were very low - and not comparable with rates yielded from other fish hosts of this area.

\section{Prey of gobies}

The abundance analysis (\% numbers) of prey revealed several differences between the 3 goby species (Fig. 10). Pomatoschistus minutus preferred benthic crustaceans such as harpacticoids or gammarids, but also some calanoids; Gobiusculus flavescens fed mainly on plankton, and to a lesser degree on gammarids, but never on harpacticoids; $P$. pictus selected plankton, but benthic crustaceans (including harpacticoids) were also important; Idotea balthica was insignificant for all gobies; mussels were only ingested by P. minutus (Fig. 10). 
a. Infested gammarids, Oct. 1990

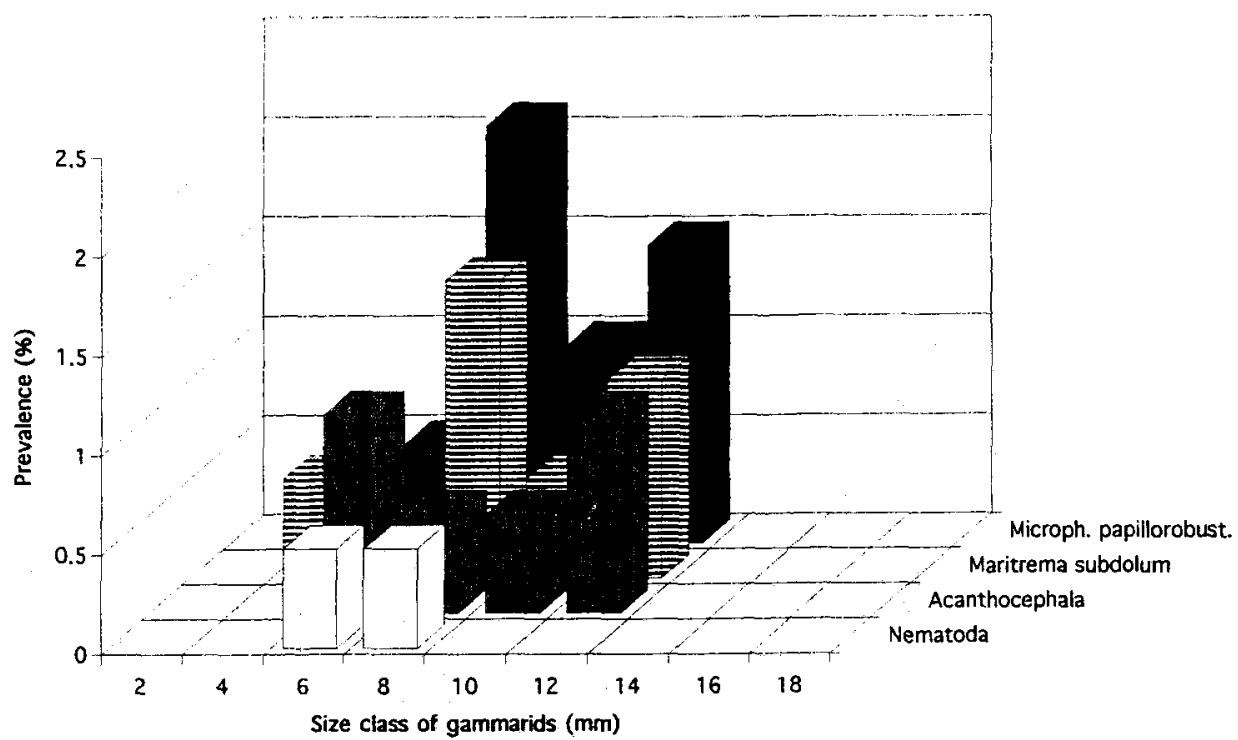

b. Available and ingested gammarids, Oct. 1990

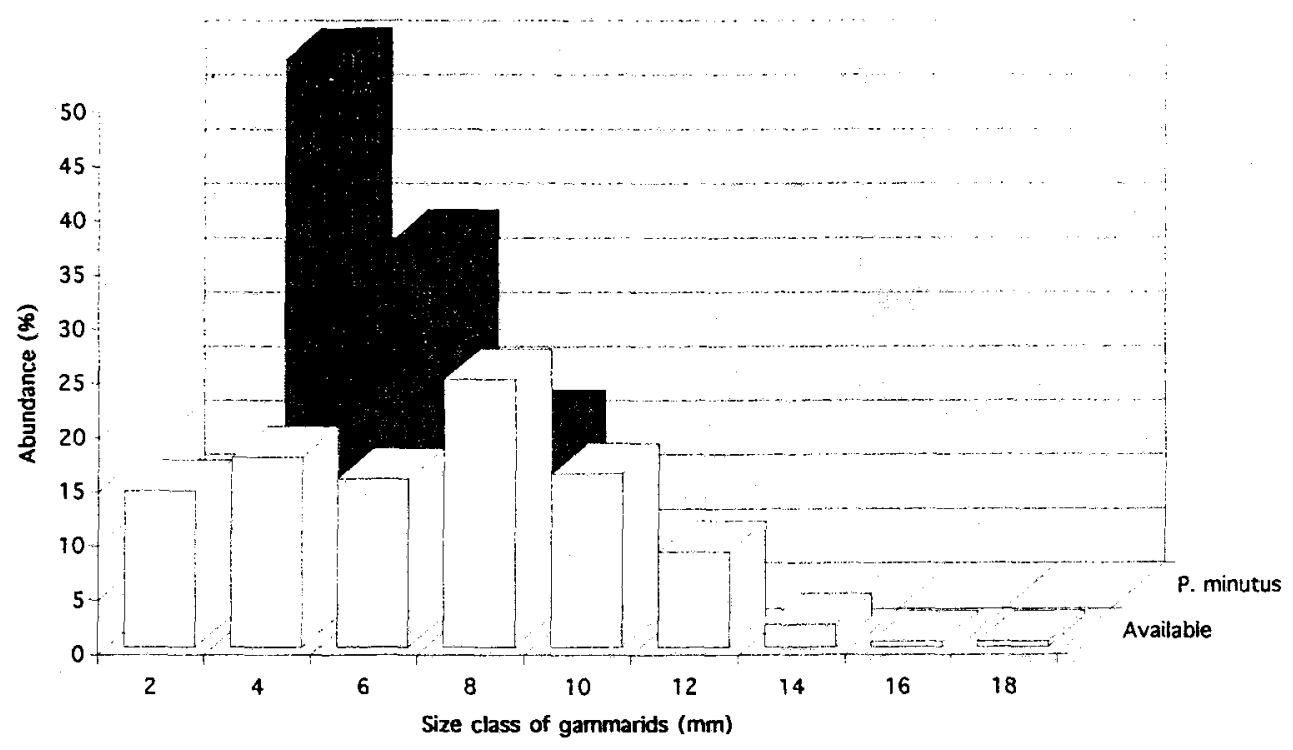

Fig. 6. Gammarid crustaceans in the food and parasite web of the Lübeck Bight in October, 1990; a: Prevalence of infestation by helminth larvae with regard to different-sized hosts; b: Percentages of available prey and that ingested by gobiid fishes with regard to size 
a. Infested gammarids, Nov. 1990

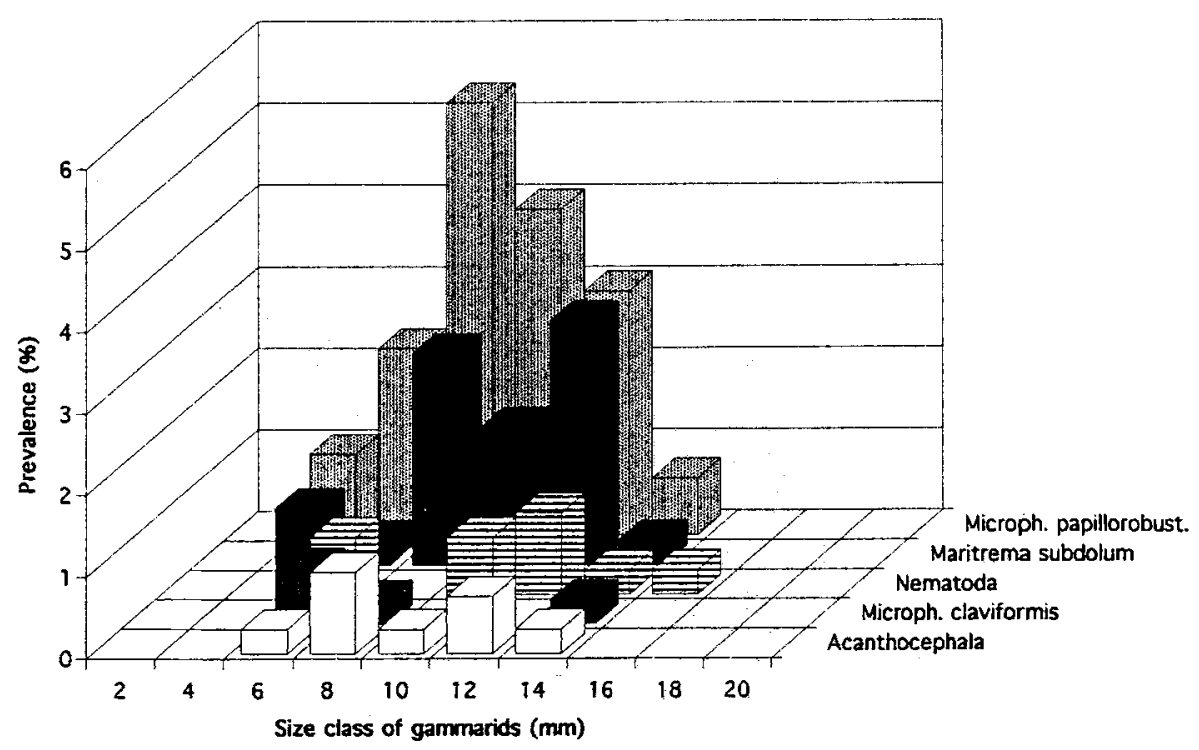

b. Available and ingested gammarids, Nov. 1990

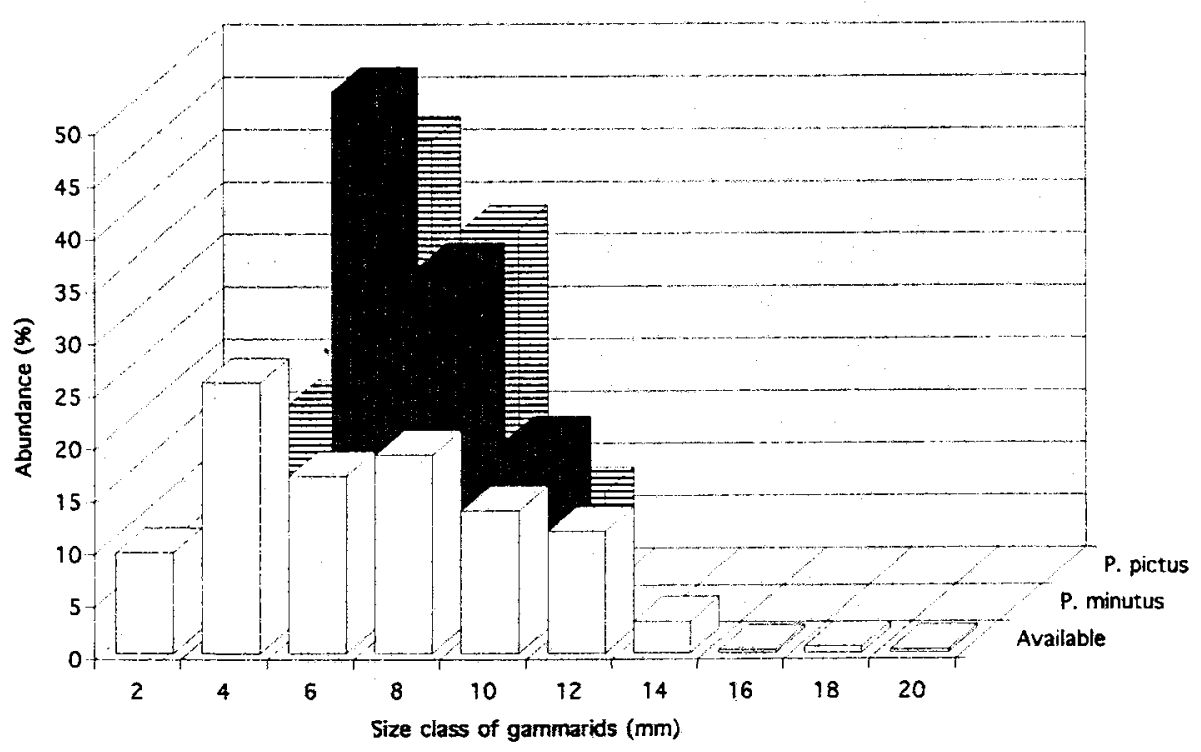

Fig. 7. Gammarid crustaceans in the food and parasite web of the Lübeck Bight in November, 1990; a: Prevalence of infestation by helminth larvae with regard to different-sized hosts; $b$ : Percentages of available prey and that ingested by gobiid fishes with regard to size 


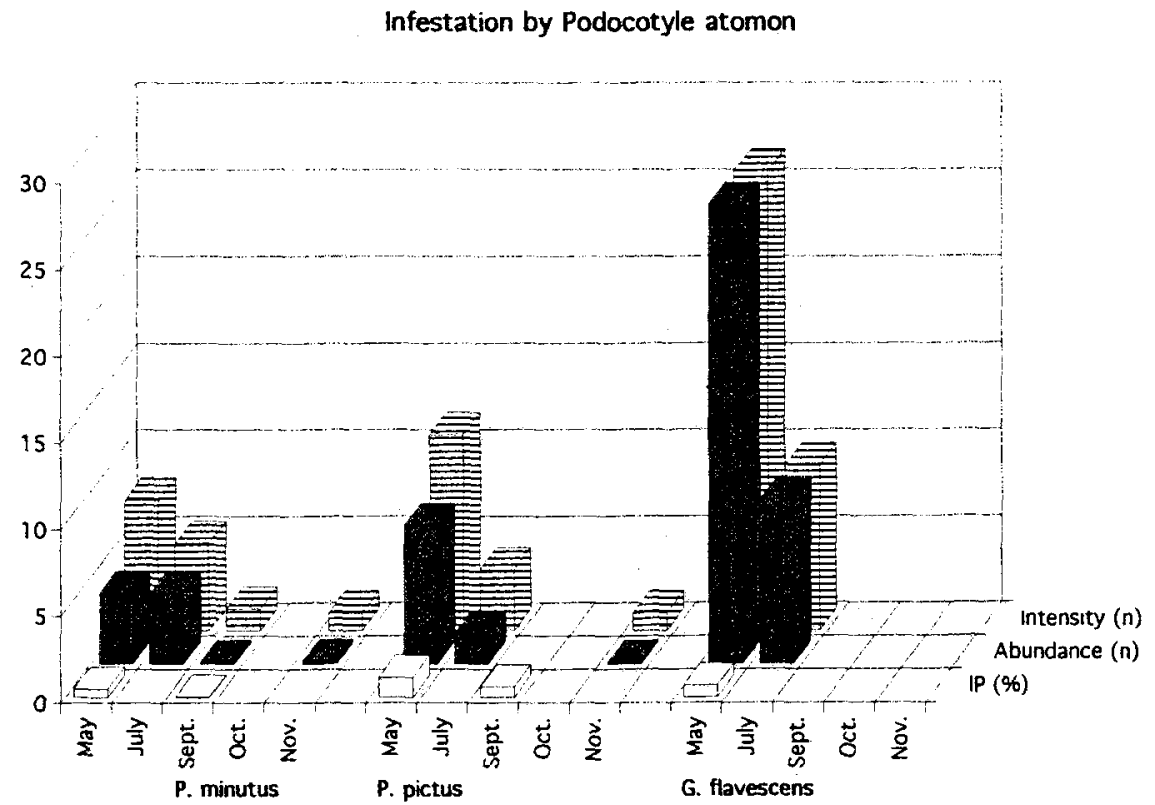

Fig. 8. Infestation potentials IP $(\%)$ of gammarids as well as abundances and intensities (mean numbers) of Podocotyle atomon in 3 goby species parasitized during 1990

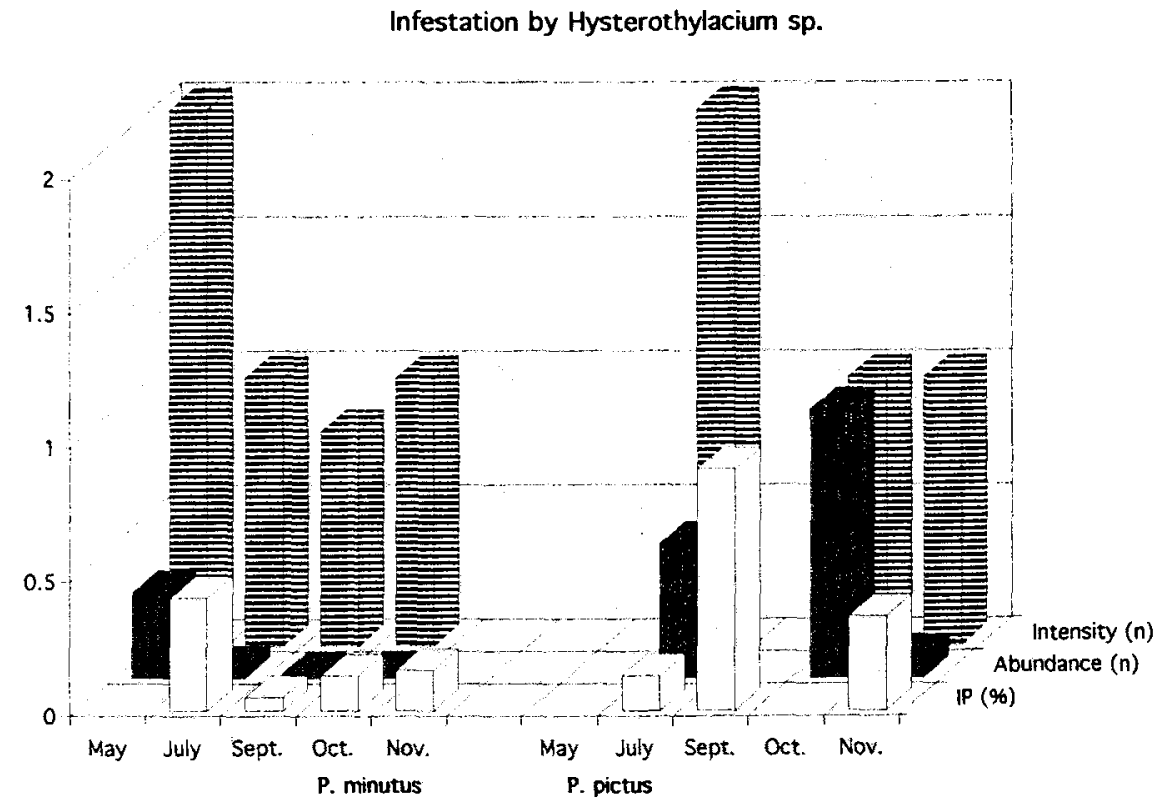

Fig. 9. Infestation potentials IP $(\%)$ of gammarids as well as abundances and intensities (mean numbers) of Hysterothylacium sp. in 2 goby species parasitized during 1990 


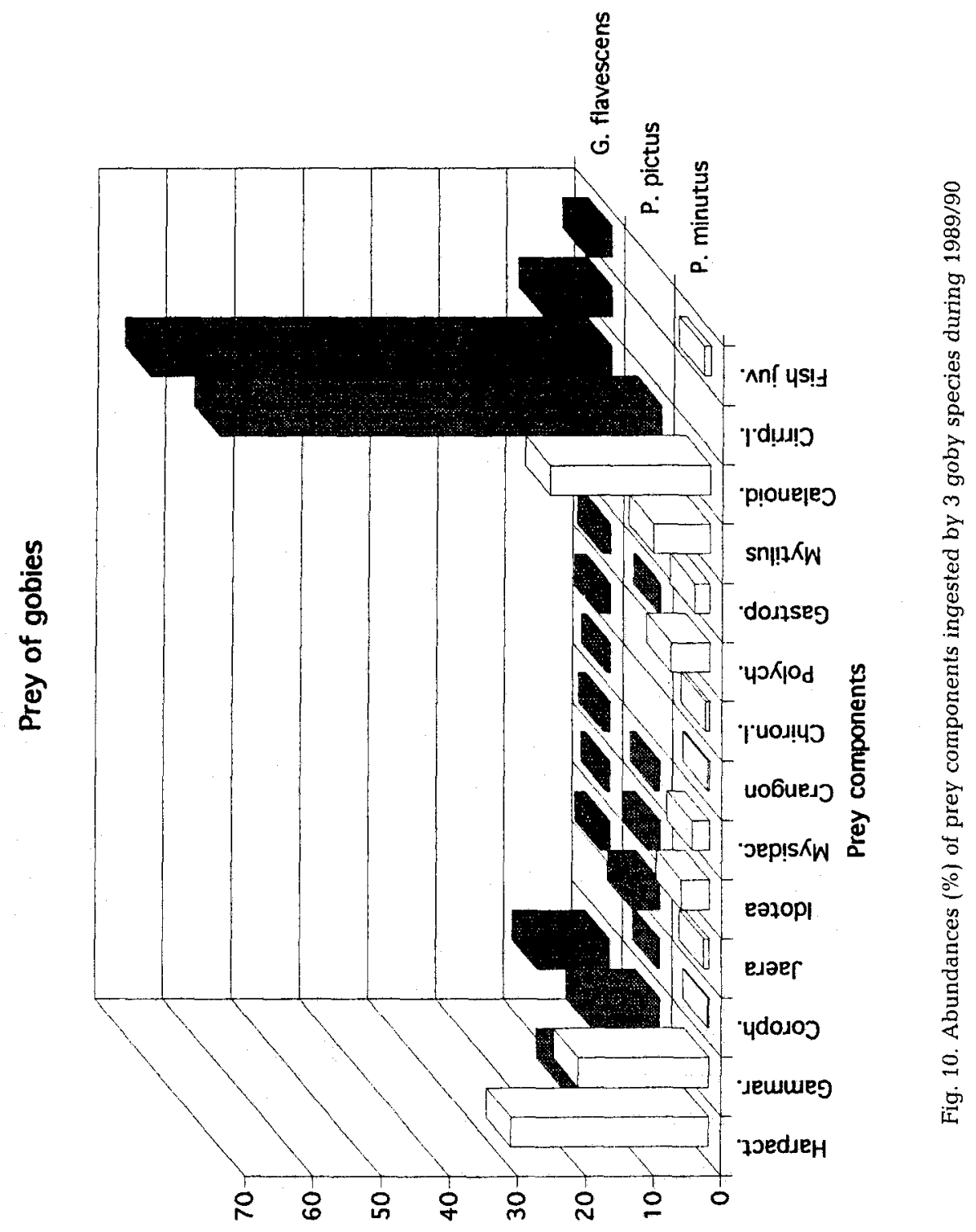

(\%) asuepunq 


\section{DISCUSSION}

Microphallids, especially Microphallus papillorobustum and Maritrema subdolum, were the most important parasites of benthic crustaceans in the Lübeck Bight. The course to their final hosts, i. e. birds, could not be pursued in this investigation. Better information on helminth transfer was obtained from the fish parasites. It seems that the values of the infestation potential (IP) are relatively low. The calculation of this index was based only on one stomach filling, with regard to size selection by the fish host. Actually, at higher temperatures, even 3-3.5 fillings per day can be assumed in gobies (Meyer-Antholz, 1986). By calculation of the reciprocal of IP, the lowest number of stomach fillings necessary for infesting a host by a parasite became apparent. The reciprocals of CestodaIP in Gobiusculus flavescens differed clearly in April or October 1989 (513 or 16, respectively). Therefore, the probability of infestation was higher in autumn than in spring for the two-spotted goby. This also applies to Pomatoschistus minutus. In contrast, intensities of Cestoda were very low in both hosts - as was already found during 1990 though prevalences of copepods were still higher (Zander et al., 1993). A large plerocercoid of Schistocephalus sp. can fill up the body-cavity of its goby hosts totally, and allows no competitor. In contrast, as many as four Bothriocephalus sp. plerocercoids which live in the stomachs of gobies can be found (Zander et al., 1993). A seasonal increase of procercoid prevalences in copepods (Gollasch \& Zander, unpubl.) may also increase the infestation rates in the next host - as was found in the brackish Schlei fjord (Zander \& Westphal, 1991; Kesting, 1992). A third tapeworm, Proteocephalus percae (often found in the Baltic), was absent at Dahmeshöved in the Lübeck Bight.

The analysis of the gammarid hosts of Podocotyle atomon and Hysterothylacium sp. emphasizes the importance of prey-size for the infestation of the next hosts. Pomatoschistus minutus selected far smaller gammarids than average from the supply available in the Lübeck Bight (Zander, 1990). This phenomenon can be confirmed by the present study, and applied also to $P$. pictus and Gobiusculus flavescens. Consequently, parasites which infest only gammarids, or other equal-sized crustaceans, have less chance of being transferred to gobiid fishes. Whereas, formerly, only gammarids of at least $9 \mathrm{~mm}$ were found to harbour Podocotyle atomon metacercariae in the Lübeck Bight (Zander \& Döring, 1989), this size-limit has decreased to $5 \mathrm{~mm}$ (Zander et al., 1993). Gammarid hosts infested by Hysterothylacium sp. L -larvae measured at least $7 \mathrm{~mm}$ (Zander \& Döring, 1989) or $4.5 \mathrm{~mm}$ (this study). The isopod Jaera albifrons which seldom exceeds $4 \mathrm{~mm}$ (Zander, 1990) already harboured nematode larvae by the time it had reached the size of $1.5 \mathrm{~mm}$. In the Schlei fjord, northern Schleswig-Holstein, Idothea spp, are also first intermediate hosts of Hysterothylacium sp. (Gollasch \& Zander, unpubl.). It is highly probable that nematode larvae found in the plankton of the Lübeck Bight (Zander et al., 1993; this study, Fig. 1) could also be Hysterothylacium sp. larvae. Køie (1993) showed that $L_{3}$-larvae of this parasite first infest several benthic and planktonic crustaceans and are then transferred to the next hosts, invertebrates and fishes.

The transmittance of tapeworm larvae from the first (copepods) to the second intermediate hosts (fish), depends first and foremost on the ways of life of the respective goby species. Whereas Gobiusculus flavescens forages on plankton during its whole life, only $P$. minutus among the Pomatoschistus spp. has a longer pelagic phase until reaching a size of $30 \mathrm{~mm}$ (Zander \& Hagemann, 1986). The abundance analysis of prey in 1989 and 
1990 revealed also strong preferences for benthic components, especially harpacticoids and gammarids, by sand gobies; whereas isopods were less exploited. $P$. pictus fed on smaller crustaceans - as indicated by the selection of smaller gammarids and greater quantities of Jaera and, in particular, calanoids.

A lot of factors may influence the life cycles of parasites, as was demonstrated in the eel-nematode Anguillicola crassus (De Charleroy et al., 1990). Prevalences of several hosts within the respective cycles were considered e.g. Podocotyle atomon (McKenzie \& Gibson, 1970), or Cryptocotyle concavum in Pomatoschistus microps (Zander et al., 1984). Size selection concerning intermediate hosts may only be important for parasite transfer, when size differences of prey and predator are moderate, as is the case between gobies and gammarids. In the case of great differences, e.g. between gobies and copepods or birds and gammarids, the real IPs simply imply the prevalences because size selection is irrelevant. This applies to the transmittance of tapeworms to gobies, and probably of microphallid flukes to birds (see Figs 3-7).

The minimal quantity of parasites transmitted from one host to the next seems to be high, following the results of this investigation. In reality, the quantity must be even larger, because there is a great loss of parasite stages during the developmental cycles. However, in addition to gammarids many other crustaceans can infest fishes with Podocotyle atomon, and Hysterothylacium sp. can be transferred by many invertebrates (MacKenzie \& Gibson, 1970; Svendsen, 1990; Køie, 1993; Gollasch \& Zander, unpubl.). The general threat to the existence of a parasite is not being able to infest the optimal host where it can mature. Whereas $P$. atomon matured in all gobies of the Lübeck Bight, Hysterothylacium sp. only did so in the larger Gobius niger, but not in small goby species (Zander et al., 1993). Another danger for parasites is lethal damage to its host by mass infestation. If gobies were able to overcome gammarids larger than $10 \mathrm{~mm}$, the infestation rates would increase even further. Zoarces viviparus specimen which fed on more and larger gammarids in the Lübeck Bight were maximally infested by 405 Podocotyle atomon and 95 Hysterothylacium sp. (Zander, 1991). This parasite load may be lethal for small gobies: maximal numbers found were 32 Hysterothylacium sp. in Gobius niger or 130 Podocotyle atomon in Gobiusculus flavescens (Zander et al., 1993). Thus, it is possible that prey selection can partially reduce the transmittance of parasites to less suitable hosts.

Acknowledgements. Thanks are due to Heiko Blessin, Barbara Janßen and Dr. Rüdiger Kock for their help during the diving operations, to Jörg Melander for supplying the 1989 plankton sample, to Françoise Marie-Claire and to Carol Berger for improving the English text.

\section{LITERATURE CITED}

Charleroy, L. de, Thomas, K., Belpaire, C. \& Ollevier, F., 1990. The life cycle of Anguillicola crassus. Dis. aquat. Org. 8, 77-84.

Esch, G. W., Gibbons, J. W. \& Bourque, J. E., 1975. An analysis of the relationship between stress and parasitism. - Am. Midl. Nat. 93, 339-353.

Esch, G. W., Shostak, A. W., Marcogliese, D. J. \& Goater, T. M., 1990. Patterns and processes in helminth parasite communities. In: Parasite communities: patterns and processes. Ed. by G. W. Esch, A. O. Bush \& J. M. Aho. Chapman \& Hall, London, $19 \mathrm{pp}$.

Kesting, V., 1992. Untersuchungen zur Parasitenfauna von Kleinfischen und Schnecken der Ostseeförde Schlei. Dipl.-Arb., Univ. Hamburg, 183 pp. 
Køie, M., 1979. On the morphology and life-history of Derogenes varicus (Müller, 1784) Looss, 1901 (Trematoda, Hemiuridae). - Z. ParasitKde 59, 67-78.

Køie, M., 1983. Digenetic trematodes from Limanda limanda (L.) (Osteichthyes, Pleuronectidae) from Danish and adjacent waters, with special reference to their life histories. - Ophelia 22, 201-228.

Køie, M., 1993. Aspects of the life cycle and morphology of Hysterothylacium aduncum (Rudolphi, 1802) (Nematoda, Ascaroidea, Anisakidae), - Can. J. Zool. 71, 1289-1296.

MacKenzie, K. \& Gibson, D., 1970. Ecological studies of some parasites of plaice, Pleuronectes platessa (L.) and flounder, Platichtys flesus (L.). - Symp. Br. Soc. Parasit. 8, 1-42.

Margolis, L., Esch, G. W., Holmes, J. C., Kuris, A. M. \& Schad, G. A., 1982. The use of ecological terms in parasitology (report of an ad hoc committee of the American Society of Parasitologists). J. Parasit. 68, 131-133.

Meyer-Antholz, W., 1986. Untersuchung über Verdauungsraten, Freßrhythmen und lokomotorische Aktivitäten der Strandgrundel, Pomatoschistus microps (Krøyer) (Gobijdae, Pisces), und ihre Anwendung zur Bestimmung der Tagesration. Diss., Univ. Hamburg, $152 \mathrm{pp}$.

Odening, K., 1974. Ontogenese und Lebenszyklus bei Helminthen und ihre Widerspiegelung in der Wirtsklassifikation. - Zool. Anz. 192,67-78.

Reimer, L. W., 1970. Digene Trematoden und Cestoden der Ostseefische als ratürliche Fischmarken. -Parasit. SchrReihe 20,144 pp.

Reimer, L. W., 1983. Zur Entstehung der Lebenszyklen bei digenen Trematoden und Cestoden. Wissensch. - Z. pädag. Hochsch. Güstrow (Math.-naturwiss. Fak.) 2, 293-306.

Svendsen, S., 1990. Hosts of third stage larvae of Hysterothylacium sp. (Nematoda, Anisakidae) in zooplankton from outer Oslofjord, Norway. - Sarsia 75, 161-167.

Zander, C. D., 1990. Prey selection of the shallow water fish Pomatoschistus minutus (Gobiidae, Teleostei) in the SW Baltic Sea. - Helgoländer Meeresunters. 44, 147-157.

Zander, C. D., 1991. Akkumulation von Helminthen-Parasiten in Aalmuttern. - Zoarces viviparus (L.) (Teleostei) der SW Ostsee. - Seevögel 12, 70-73.

Zander, C. D. \& Döring, W., 1989. The role of gobies (Gobiidae, Teleostei) in the food web of the shallow habitats of the Baltic Sea. In: Proceedings of the 21st European Marine Biology Symposium, Gdansk, 1986. Ed. by R. Z. Klekowski, E. Styczinska-Jurewicz \& L. Falkowski. Polish Academy of Sciences, Institute of Oceanology, Wroclaw, 499-508.

Zander, C. D. \& Hagemann, T. 1986. Fluctuations of prey, abundance and biomass of gobies (Gobiidae, Pisces) in a shallow habitat of the western Baltic Sea. - Zool. Anz. 216, 289-304.

Zander, C. D. \& Westphal, D., 1991. Kleinfischparasiten der Ostseeförde Schlei und ihre Einbindung in die Nahrungskette. - Seevögel 12,4-8.

Zander, C. D., Kollra, G., Antholz, B., Meyer, W. \& Westphal, D., 1984. Small-sized euryhaline fish as intermediate hosts of the digenetic trematode Cryptocotyle concavum. - Helgoländer Meeresunters. 37, 433-443.

Zander, C. D., Strohbach, U. \& Groenewold, S., 1993. The importance of gobies (Gobiidae, Teleostei) as hosts and transmitters of parasites in the SW Baltic. - Helgoländer Meeresunters. 47, 81-111. 